\title{
Disease Decision Support Systems: Their Impact on Disease Management and Durability of Fungicide Effectiveness
}

\author{
Odile, Carisse ${ }^{1}$, David-Mathieu, Tremblay"1, \\ Tristan, Jobin' ${ }^{1}$, and Anne Sophie, Walker ${ }^{2}$ \\ ${ }^{1}$ Agriculture and Agri-Food Canada \\ 2Institut National de la Recherche Agronomique, \\ Unité de Recherche BIOGER-CPP, Thiverval-Grignon, \\ ${ }^{1}$ Canada \\ ${ }^{2}$ France
}

\section{Introduction}

In modern agriculture, fungicides play a major role in maintaining crop health and reliable yields of products that meet the demand for high quality. Hence, fungicides represent a key component of most integrated disease management programs, and their effectiveness should be sustained as much as possible. However, fungicide effectiveness has been significantly affected by the development of resistance in some fungal pathogen populations. Moreover, environmental considerations are becoming increasingly important and, as a consequence, it is less acceptable to apply fungicides needlessly. In this chapter we intend to demonstrate that disease decision support systems could help reduce fungicide usage and as a consequence maintain the durability of fungicides effectiveness. This will be done using apple scab, caused by the fungal pathogen Venturia inaequalis as a model system. In most apple producing areas of the world, apple scab is the most important disease and its control depends almost exclusively on frequent use of fungicides; in some areas up to $75 \%$ of all pesticides used are applied to control apple scab. Apple scab is a complex disease that develops following two phases; a monocyclic phase caused by ascospores produced in pseudothecia originating from leaf lesions present the previous fall, and a polycyclic phase produced by conidia originating from lesions on leave and fruits. Various management tactics to manage apple scab were developed during the last half century. These tactics are either biologically/culturally or chemically based. However, in most IPM programs, the control of apple scab is based on the use of fungicides and these programs are developed to improve fungicide efficacy using procedures to estimate potential ascospore dose, weatherbased models to estimate ascospore maturity, leaf growth and risk of infection periods. These tools were integrated into various disease decision support systems (DDDS). Almost all of the DDSS focus on management of primary infections (monocyclic phase) and much less attention has been paid to secondary infections (polycyclic phase) that develop during the summer, despite that up to 6-8 additional fungicide sprays are often used to manage 
summer scab. This review discusses the basic approaches for managing apple scab and their effect on durability of fungicide effectiveness.

\section{The paradigm and dilemma of disease management in modern agriculture}

In most parts of the world, plant diseases induce loss of food crops. Therefore, diverse control measures were developed for suppression or management of plant pathogens. There is a general consensus in the scientific community to consider that sustainable disease management could be achieved only through the integration of several control measures including cultural, physical, genetic, biological and chemical measures. These control measures, however, differ in efficacy, duration of effectiveness and cost. In addition, the occurrence of plant pathogens and the severity of the diseases they cause often vary from year to year, location to location, from a production system to another... hence rational and cost-effective disease management necessitates the consideration of several factors, so reaching an informed and rational decision for disease management is a complex task. In addition to agronomic considerations, growers must deal with economic and social considerations which include the value of the crop, the tolerance level of the consumers to presence of diseases (or pathogens) and the consumer's concerns regarding pesticide use and residues on food products.

In practice, grower's decisions regarding disease management are generally based on risk. The factors that influence grower's perception of risk are mainly related to the value of the crop and the characteristics of the pathogen being considered. In intensive production systems (high-value crops) the economic threshold for disease damage is generally low. In other words, it is generally more profitable to apply a control measure than to tolerate even a low level of damage. On the contrary, in extensive production systems (low value crops), depending on disease pressure, it is not always cost-effective to apply a control measure. Another important factor related to disease management decision is the potential of the disease to cause damages. Some diseases are more destructive than others and under favourable conditions may develop rapidly eventually leading to complete destruction of the crop, for example potato late blight, caused by Phytophthora infestans or apple scab caused by $V$. inaequalis. Thus, from a crop production standpoint, the decision as to apply a disease control measure mainly depends on: the value of the crop, the type of disease and its potential to causes losses, and on the cost of control measures. Hence, chemical control is often perceived as the most effective control measure. However, the intensive and sometime solely use of fungicides to manage some diseases resulted in disease management practices that can harm human health as well as the environment. In addition, as the use of fungicides has increased, so has the incidence of resistance to certain classes of fungicides.

The dilemma of crop disease management in the $21^{\text {th }}$ century could be summarized as follow: food crops must be produced in sufficiently large amount to avoid food shortage; it should be free of diseases to respond to the consumer demand and to be shipped over long distances or stored for prolonged period of time; crop production should be profitable for growers but not too expensive for the consumers; it should be within acceptable limits of pesticide residues and produced in such way that it will not harm the environment. Various disease management strategies were developed in response to some of these considerations including biological control, use of resistant cultivars and integrated disease management. However, disease management practices cannot be divorced from economics and farmers cannot implement disease management strategies that are not cost-effective. Hence, it is 
expected that fungicides will continue to play a role in disease management programs, especially in intensive production systems. However, to maintain their effectiveness and to minimize their effect on human health and on the environment, they should be used in a rational and informed way. One approach to achieve this goal is to use disease decision support systems.

To illustrate the benefits of using DDSS to manage diseases with fungicide we shall use the example of apple scab. In most parts of the world, apples are produced in intensive monocrop production systems. Apples are generally considered as high value crop because the costs per ha of implementing and maintaining an orchard is high. Apple tree is a perennial crop, hence several cultural control practices are impossible or difficult to implement, for example crop rotations. Apple scab is a typical disease for which growers are risk adverse because any failure in controlling infections on fruits will result in economic losses (MacHardy, 1996). Since almost a century, researches were conducted on $V$. inaequalis biology and ecology, on host-pathogen relationships, and on apple scab epidemiology and management, (Aylor, 1998; MacHardy, 1996). As a result, the disease has been adequately managed, but durable management practices have not yet been attained. Apple scab management is largely, if not exclusively, based on fungicide applications and up to recently, this approach was cost effective. In North America as well as in several countries, the market constraint for high-quality blemish-free fruits and the technical hitches of achieving control once the disease has become established in the orchard have led to the application of regular fungicide sprays, applied from bud-break to harvest (MacHardy, 1996). Such spray programs, though costly, have usually proved successful, reliable and simple for farm managers to implement. However, pesticides are often regarded as highly undesirable by consumers and there is an ongoing negative media campaign against them. As a consequence, several retailers have identified the occurrence of pesticide residues as being one of the prime concerns of consumers about fresh products. Moreover, with the rising costs of chemicals, and increasing resistance to fungicides in several pathogens' populations, such practices have become less acceptable. Methods of optimizing fungicide use are thus now being sought.

\section{Understanding the pathogen: life cycle of Venturia inaequalis}

Venturia inaequalis (Cke.) Wint. (Spilocaea pomi) (Ascomycetes, Pleosporales, Venturiaceae) causes apple scab, scurf, and black spot on apple (Malus pumila). Apple scab infections are mostly visible on leaves and fruits. On leaves lesions develop first as an area of lighter shade of green compared to the rest of the leaf (Fig. 1a). Rapidly, the lesions become covered with fungal mycelium and spores giving an olive-dark-green and velvety appearance to the lesion (Fig. 1b). Under severe infections, the entire leaf can be covered by lesions giving rise to a symptom called 'sheet scab' (Fig. 1c). When sheet scab is present it can lead to premature partial or complete tree defoliation. Lesions on fruits are generally smaller and become corky with age (Fig. 1d). When the fruits are infected early in the season, large lesions which deform the fruit and may cause premature fruit drop (Fig. 1e). Fruit infections that occur in late summer or early fall often lead to symptoms that are visible only after harvest, during storage. These lesions are small and this symptom is call 'pin point scab' (Fig. 1f).

In most parts of the world, apple scab epidemics are initiated by ascospores arising from sexual reproduction occurring the previous fall. There is one sexual infection cycle per year and the amount of ascospores depend on the amount of disease present in the orchard the 


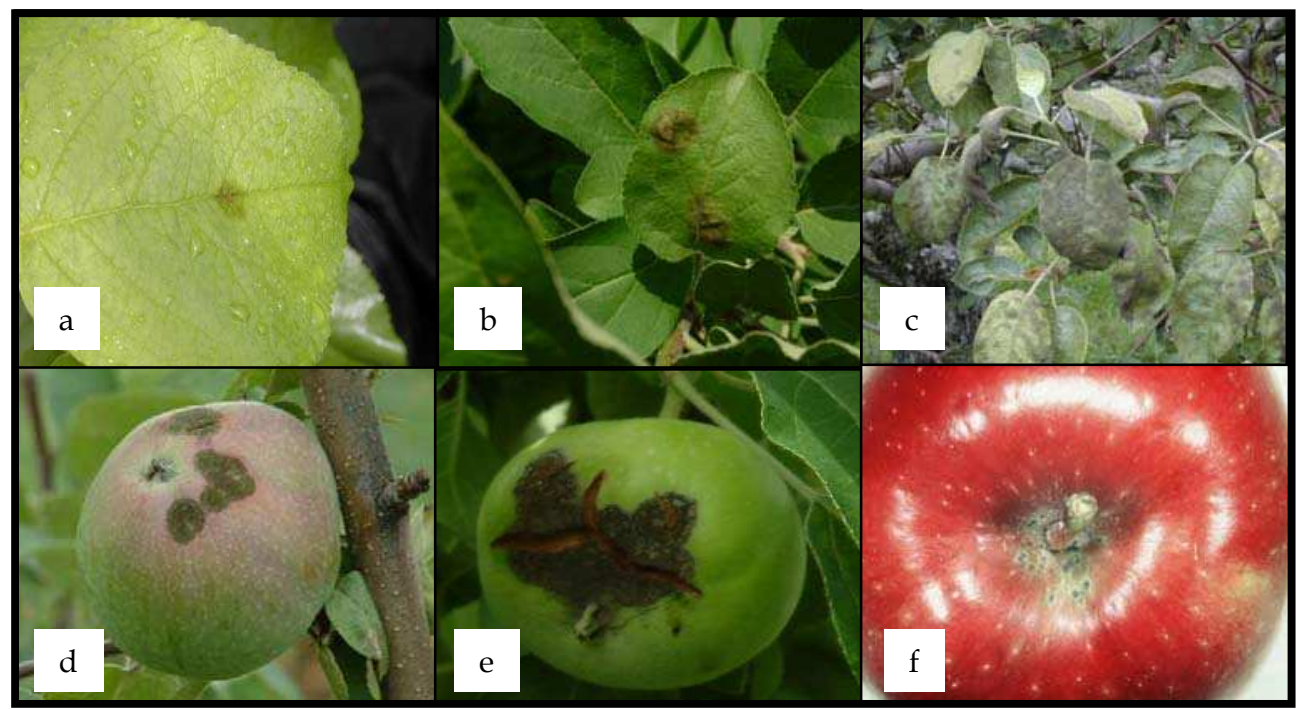

Fig. 1. Symptoms on apple leaves and fruits caused by Venturia inaequalis: Newly developed lesions on apple leaves (a); well developed lesions on leaves (b); symptoms of sheet scab (c); lesions on fruit (d); fruit deformation caused by early infections (e); pin point scab (f).

previous fall and the weather conditions during the winter. In apple production areas with mild winters, $V$. inaequalis can also overwinter as conidia arising from asexual reproduction. In these areas, conidial primary inoculum overwinters on wood and in bud scales (Beker et al., 1992). Nevertheless, in most areas where apple scab is a problem, the ascosporic inoculum is the main source of inoculum and plays a highly significant role in epidemic development. The complete life cycle of $V$. inaequalis is depicted in Figure 2. Briefly, the pathogen overwinters as pseudothecia (fruiting bodies) in infected fallen leaves on the orchard floor. In early spring, pseudothecia mature in response to increasing temperatures and to alternating wetting and drying of apple leaves litter. The primary infections are caused by ascospores released from mature pseudothecia and in general, first ascospores are released at the 'green tip' apple tree phonological stage. Ascospores are released during a period of 8 to 12 weeks with a peak around bloom. The ascospores are forcibly discharged form the pseudothecia in leaf litter, become airborne and wind dispersed. When the ascospores are deposited on apple leaves, the infection process (spore germination, penetration and colonization of leaf tissue) begins provided that there is a film of water on the leaf surface and that the air temperature is above $0^{\circ} \mathrm{C}$ (Mills , 1944; Mills and Laplante, 1951). The infection efficiency is influenced by the temperature during the leaf wetness period; longer the wet period higher the infection efficiency (Mills and Laplante, 1951). Depending on leaf age, temperature and humidity, 9-21 days after the beginning of spore germination, typical olive-green, velvety lesions develop on the site of infection (Fig 1.). Conidial production begins shortly after lesions become visible, each scab lesions having a potential to produce up to 100,000 new conidia. Conidium productivity of individual lesion is influenced by cultivar, humidity, photoperiod and temperature (Dewdney et al., 2003). Newly produced conidia are wind and rain splash dispersed (Aylor, 1998). The conditions that influence conidial infections are similar to those influencing ascospore infections 
(Hartman et al., 1999). As for the leaves, fruit infection efficiency is influenced by the cultivar, fruit age, inoculum dose, temperature and fruit wetness duration (Schwabe et al., 1984; Xu and Robinson, 2005). V. inaequalis life cycle is completed by sexual reproduction and initiation of new pseudothecia in late autumn (Fig 2.).

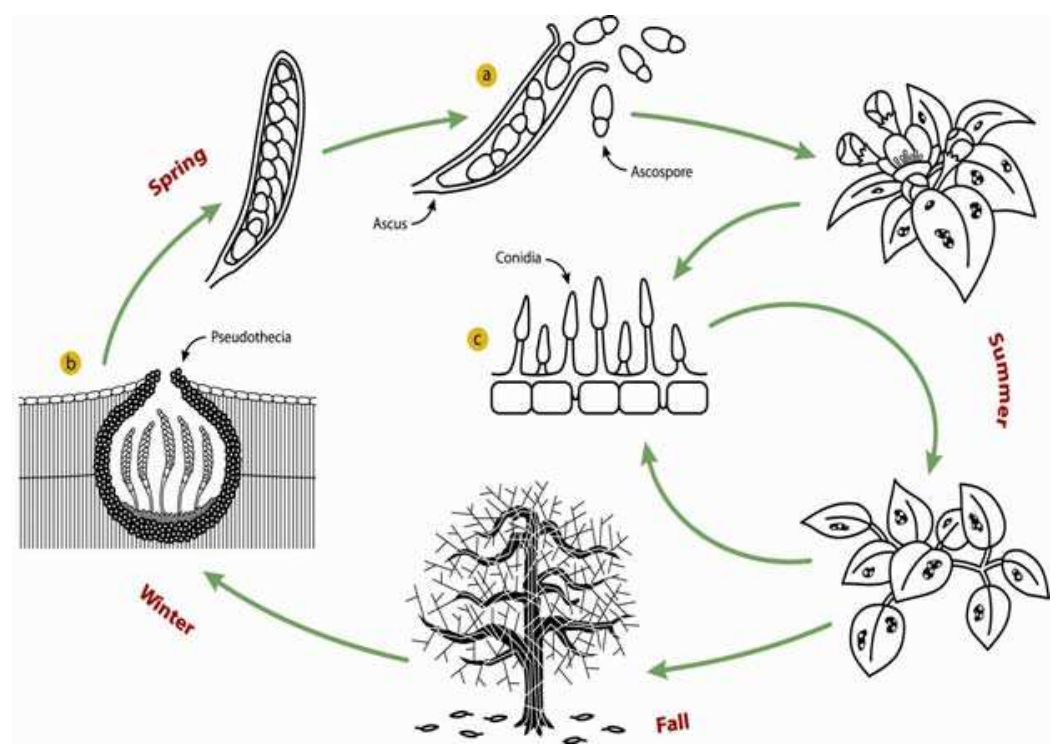

Fig. 2. Life cycle of Venturia inaequalis showing the ascospores (a) responsible for the primary infections produced in pseudothecia (b) and the conidia (c) responsible for the secondary infections.

\section{Understanding the disease: epidemiology of apple scab}

Understanding how plant pathogen populations increase over time is critical for developing appropriate management practices. Apple scab epidemics comprise three phases. The first phase corresponds to the overwintering period and is often referred as the inactive phase. The second phase, called the primary infections period, is caused by ascospores produced in overwintered pseudothecia (Fig. 2-a-b). This phase is monocyclic because no new ascospores are produced until the following spring. The second phase, called the secondary infections period, is caused by conidia produced on leaf and fruit lesions (Fig. 2c). This phase is polycyclic because new conidia are produced on new lesions until the end of the season. The quantity of initial ascosporic inoculum $\left(\mathrm{Qa}_{0}\right)$ is proportional to the quantity of disease the previous fall $\left(\mathrm{Y}_{\max }\right)$ and is often referred as the potential ascospore dose (PAD). During the monocyclic phase the disease, severity will increase to reach a maximum denoted by $Y_{\text {max }}^{\prime}$ determined by the amount of ascosporic inoculum $\left(\mathrm{Qa}_{0}\right)$ and on suitability of weather for infection. In other words, the primary scab severity is limited by the amount of primary inoculum, higher is the quantity of ascospores, higher is the potential for primary infections (Fig. 3). During the polycyclic phase, the initial conidium inoculum is proportional to the amount of disease $\left(\mathrm{Y}_{\text {max }}^{\prime}\right)$ at the end of the monocyclic phase $\left(\mathrm{Qc}_{0}=\mathrm{f}\left[\mathrm{Y}^{\prime}{ }_{\max }\right]\right)$ (Fig. 3). The 
polycyclic epidemic may overlap monocyclic epidemics resulting in a rapidly progressing epidemic. These characteristics of apple scab epidemics are the foundations of most strategies to manage the disease. In theory, effective control of primary infections should result in low risk of secondary infection and hence allow for a more relaxed fungicide spray program during the summer. Thus, in most part of the world, the strategies to manage apple scab aim at controlling primary infections in order to avoid secondary infections and secondary inoculum build-up which will render management difficult and the objective of $1-2 \%$ fruit scab at harvest unattainable.

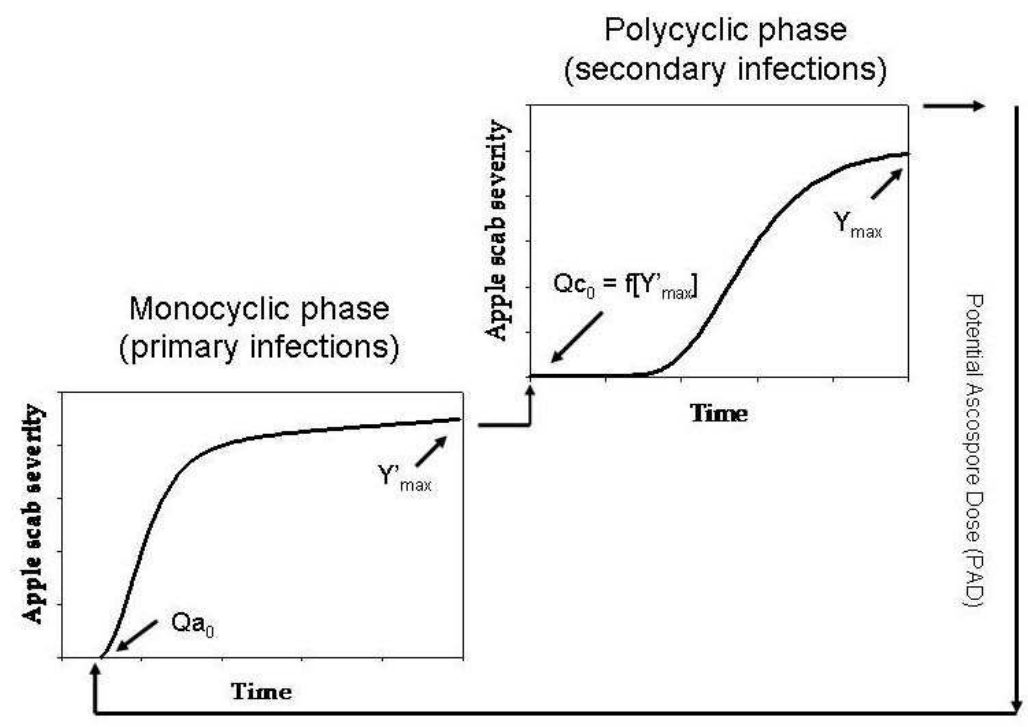

Fig. 3. Diagram describing the relationship between the monocyclic and polycyclic phase of the development of apple scab (Venturia inaequalis). $\mathrm{Qa}_{0}$, is the quantity of ascosporic inoculum at the beginning of the primary infection period (monocyclic phase); $Y^{\prime}{ }_{\max }$, the final disease severity at the end of the primary infection period, $Q \mathrm{c}_{0}$, the quantity of conidial inoculum at the beginning of the secondary infection period (polycyclic phase); and $Y_{\max }$ the final disease severity at the end of the secondary infection period.

\section{Development of disease decision support system (DDSS)}

Even though, the term 'epidemic' is often used to describe a disease that develops sporadically and causes high level of damage, in this review we define epidemic as the dynamic of disease, explicitly, the change in the amount of disease with time. We defined the term 'model' as a simplified representation of a pathosystem. Botanical epidemiologists developed a large amount of models that could be used to make decisions regarding disease management and to improve our understanding of epidemic development. As a result, there is a variety of models that range from set of rules; mathematical equations; to dynamic simulation of epidemics. In botanical epidemiology an epidemic is the result of the interactions between a population of hosts (ex apple trees) and a pathogen population (ex. $V$. inaequalis). This interaction is constantly influenced by external factors such as climatic 
conditions, cultural practices, aggressiveness of the pathogen, etc. (Table 1). These factors are related and interact together resulting in complex multilevel interactions denoted as a pathosystem. In some pathosystems, it is virtually impossible to model all interactions; hence the first step in modeling an epidemic is to identify the interactions that are essential for the progress of the epidemic.

\begin{tabular}{|l|l|l|}
\hline Pathogen & Host & Environment \\
\hline $\begin{array}{l}\text { Abundance of pathogen (ascospore } \\
\text { and conidial dose) }\end{array}$ & $\begin{array}{l}\text { Susceptibility (quantitative or } \\
\text { qualitative) }\end{array}$ & Temperature \\
\hline Pathogenicity /aggressiveness & $\begin{array}{l}\text { Single or mixed cultivars } \\
\text { planting }\end{array}$ & Rainfall / Dew \\
\hline $\begin{array}{l}\text { Adaptability to host resistance or } \\
\text { fungicides }\end{array}$ & $\begin{array}{l}\text { Ontogenic resistance in leaves } \\
\text { and fruits }\end{array}$ & $\begin{array}{l}\text { Leaf wetness } \\
\text { period }\end{array}$ \\
\hline $\begin{array}{l}\text { Dispersal efficiency (long and short } \\
\text { distance) }\end{array}$ & Tree density, pruning, & Wind \\
\hline $\begin{array}{l}\text { Survival efficiency (winter } \\
\text { survival) }\end{array}$ & Tree health & Soil properties \\
\hline Reproductive fitness & & Pesticide damage \\
\hline
\end{tabular}

Table 1. Example of factors that influence the dynamic of the apple scab pathosystem

The general approach in developing DDSS is to examine separately each important process in the pathogen life cycle and to model the factors which significantly influence the progress of this process. The resulting sub-models are depicted as diagrams and generally link together within a simulation program (Fig. 4). For apple scab, the pathosystem is defined as the general interaction between apple trees and $V$. inaequalis, the models representing the various process and sub-processes include the mathematical models relating weather conditions to overwintering of pseudothecia, maturation of pseudothecia, discharge of ascospores, dispersal of ascospores, leaf infections, spore germination, fungal colonization, sporulation, etc (Fig. 4).

\section{Models describing the major sub-processes of apple scab epidemics}

\subsection{Models for estimating potential ascospore dose}

As shown in Figure 3 and 4, the amount of primary inoculum is influenced by the amount of disease present the previous fall and to a less extent by the conditions during the winter months. Hence, MacHardy and coworkers developed the concept of Potential Ascospore Dose (PAD). Initially, the PAD was derived from lesion density, pseudothecial density, ascal density, leaf litter density, and the number of ascospores per ascus, and was expressed in ascospores per square meter of orchard floor (MacHardy, 1994; MacHardy 1996). Gadoury and MacHardy (1986) studied the relationship between PAD values and most of the variables used to calculate PAD values. They reported that the most important variables influencing variation in PAD values was the number of lesions $/ \mathrm{m}^{2}$ of apple leaf tissues and the percent leaves infected (scab incidence). From this work, it was concluded that the PAD could be derived from leaf scab incidence just prior to leaf fall. To facilitate the adoption of the PAD concept, a non-sequential sampling procedure was develop based on the relationship between leaf scab incidence on 600 extension shoots (10 shoots by 60 trees) and PAD values. However, the requirement to sample 600 shoots limited grower adoption of the 
sampling procedure. As a result, a sequential sampling procedure was developed based on the analysis of 66 fall assessments of leaf scab (MacHardy et al., 1999; Reardon et al., 2005). This sampling procedure is use to classify orchards as "low risk" or "high risk" (Reardon et al., 2005).

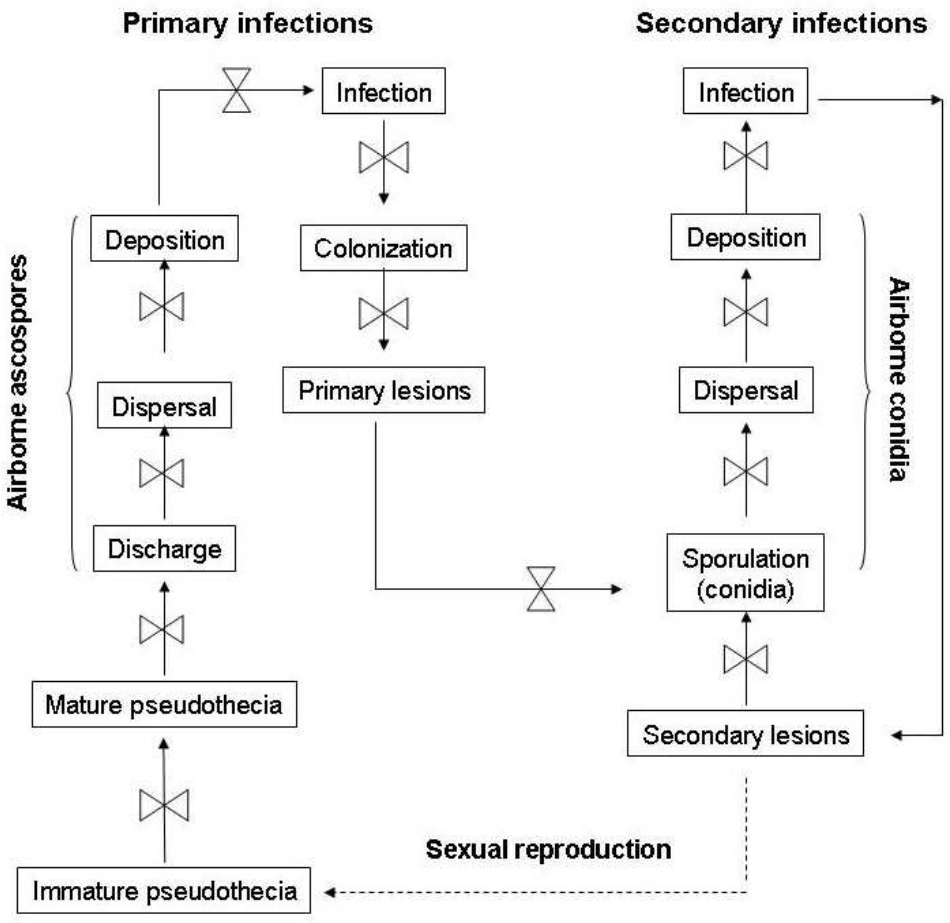

Fig. 4. Schematic representation of the relationships between the most significant subprocesses in apple scab epidemics

\subsection{Models for estimating ascospore maturity}

The monocyclic phase of apple scab development begins when the first ascospores are ejected and ends when the stock of ascospores is exhausted hence these biofixs represent the temporal boundary of the primary infection period. A widespread principle shared by most apple scab management programs is that the fungicide spray program could be ended or interval between fungicides applications increased when the seasonal stock of ascospores is exhausted. From a management standpoint, it is thus crucial to know or estimate accurately ascospore maturity and release. Ascospore maturity could be assessed by visual observations of pseudothecia and release by spore trapping. Work by Carisse et al. (2006) and Charest et al. (2002) on spatial distribution of airborne ascospores suggested that several traps would be required because of spatial heterogeneity in inoculum density and that the detection threshold may be lower than the density of airborne ascospores in a well-managed orchard. In addition, information of airborne ascospore concentration has no predictive value because by the time the information become available, infection already took place. 
Hence, in practice, the period of availability of ascospores is predicted using models. The rate of ascospores maturation is mostly influenced by temperature; hence most models predicting ascospore availability are temperature-based. These models were developed to predict the first ascospore release (Proctor, 1982; James and Sutton, 1982) or the temporal dynamics of ascospore maturity (Gadoury and MacHardy, 1982; Rossi et al., 2000; Schwabe et al., 1989). The models most commonly used to predict ascospore availability use degreeday accumulation (Tbase $0{ }^{\circ} \mathrm{C}$ ) to predict proportion or percent of matured ascospores (Fig. 5).
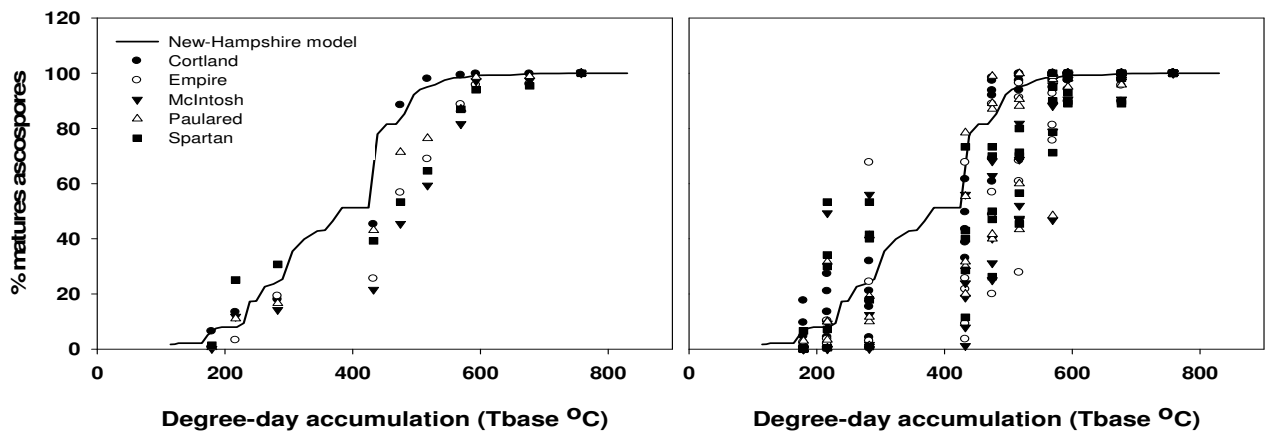

Fig. 5. Relationship between percent mature ascospores of $V$. inaequalis released from leaves of the cultivars Cortland, Empire, McIntosh, Paulared, and Spartan and degree-day accumulation since 50\% silver tip (McIntosh). Percent mature ascospores are presented as average of 10 observations (left) and as individual observations (right). Lines represent the predicted values calculated from the model published by Gadoury and MacHardy, 1982.

\subsection{Models to estimate risk of primary infections}

Almost all DDSS developed for apple scab management are using the pioneer work of Mills and Mills and Laplante (Mills, 1944; Mills and Laplante, 1951). Before the Second World War, the only fungicides available for management of apple scab were sulphur and lime sulphur. To be efficient, sulphur must be applied before an infection event; the closest from the event the higher efficacy. Lime sulphur has some post infection activity provided that it is applied within few hours after the infection event. Hence tools were needed to determine the risk of infections. Mills (1944) analyzed available data on efficiency of primary infections as a function of duration of leaf wetness (hours) and temperature during the leaf wetness period $\left({ }^{\circ} \mathrm{C}\right)$ and built a first table that relates the risk of infection to any combinations of leaf wetness duration at temperature ranging from 5 to $26^{\circ} \mathrm{C}$. Mills and Laplante (1951) collected additional data during 20 years and concluded that minimum leaf wetness period required for infection was about 1.5 times longer than reported earlier. From his observations a table that depict the risk of $V$. inaequalis infections as a function a leaf wetness duration and temperature during the wet period (Fig. 6) was proposed. The initial version of this table commonly called the Mills' table was modified by several researchers to account for discontinuous leaf wetness period and conidial infections (Becker and Burr, 1994; Hartman et al., 1999; Schwabe, 1980; Sys and Soenen, 1970) and to extend the range of temperatures, mainly low temperatures, included in the table (Stensvand et al., 1997). 


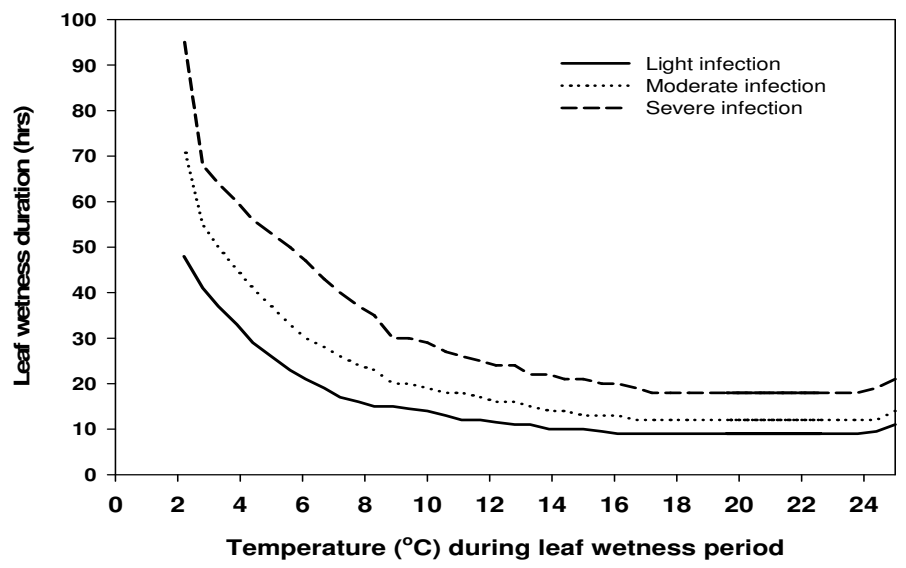

Fig. 6. Severity of infection by $V$. inaequalis as a function of temperature and surface wetness duration (hours) (Mills, 1944; Mills and Laplante, 1951).

These models form the foundation of most apple scab management programs which predominantly focus on management of primary infections (MacHardy, 1996). Much less attention has been paid to secondary infections, mainly because they are often assumed to depend largely on primary infections (Carisse et al., 2009; Holb et al., 2005). In the absence of management tools for summer scab, however, risk-averse growers may apply fungicides regularly, potentially resulting in an additional 6 to 8 sprays, whereas growers who are convinced that they have achieved adequate primary infection control may not spray enough during the summer, potentially resulting in yield losses (Holb et al., 2003; Holb et al., 2005; MacHardy, 1996). Nevertheless, despite the large amount of research that has been done on apple scab, the disease is still one of the most destructive and economically important disease in several apple production areas. Scab management may require 6 to 16 sprays annually depending on disease pressure, cultivar susceptibility, weather conditions, and marketing objectives (Reardon et al., 2005, Van der Sheer, 1992, Holb et al., 2005). Intensive use of fungicide in apple production has led to unstable control as fungicide resistance arose. The development of fungicide resistance is influenced by several factors such as the mode of action of the fungicide, the biology of the pathogen, and fungicide use pattern. Understanding how resistance develops, and how it can be managed is key to warrant sustainable disease control with fungicides.

\section{Sustainability of fungicidal disease control}

\subsection{Fungicides used to manage apple scab}

Fungicide used to manage apple scab could be divided into two types: protectant and penetrant. The protectant fungicides also called pre-infection fungicides are active on the plant surfaces where they stay after application. These fungicides do not penetrate into the plant; hence they can be washed off the plant and must be re-applied to new growth that develops after application. These fungicides, for example captan, are applied before 
infections take place to inhibit the early stage of the infection process such as spore germination and penetration. Therefore protectant fungicides must be applied before the beginning of an infection, generally initiated by a rain event, or within 24 hours after the beginning of the infection. At a later stage of the infection process, the fungicide must penetrate through the outer surfaces of the apple leaves and fruits to reach $V$. inaequalis already grown inside the tissues. The penetrant fungicides, often referred as systemic or post-infection fungicides are absorbed into plants. These fungicides have different mobility into the plant. Some are locally systemic, moving on a short distance generally only within a few layers of plant cells, while others have a translaminar movement, moving from one side of a leaf to the other. Within a few hours of application, penetrant fungicides become rain fast. Several penetrant fungicides inhibit fungal growth and sporulation; hence they are effective when applied after spore penetration into the apple tissues. However, they have limited curative ability because they are effective only within the first 24- to 96-hour after fungal penetration into the plant.

Fungal pathogens including $V$. inaequalis, represent a community of different individuals with different sensitivities to fungicides. When the community is exposed to a fungicide, the surviving population is mostly constituted of individuals with reduced sensitivity that will better survive, reproduce and then increase their relative proportion in the population, treatment after treatment. At the individual level, in phytopathogenic fungi, reduced sensitivity is the result of a single or multiple changes (mutation, insertion or deletion) in the fungal genome, most often in the fungicide target genes. Reduced sensitivity to the fungicide is an ecological advantage under fungicide selection pressure; hence the proportion of less sensitive or resistant individuals will increase in sprayed fields if their fitness is not altered. The rate of increase in proportion of resistant individuals depends upon the initial frequency of resistance in the population, the biology of the fungus (population dynamics, number of cycles per season, migration, recombination due to the sexual stage...), the fungicide (mode of action, mainly single-site or multi-site, the resistance mechanism, possibly driven by a single or several genetic changes, and the fitness cost associated to the resistance mechanism) and the pattern of use of the fungicide (number and sequence of treatments, dose, anti-resistance strategies). Among these risk components, the number of genetic changes conferring the resistance is of major importance. When single genetic changes are involved, a rapid change toward resistance may arise (qualitative resistance), leading to a population that is largely resistant, and disease control failure. When multiple genetic alterations are involved, the change toward resistance develops gradually (quantitative resistance), leading to a reduced sensitivity of the entire population. The risk of resistance development in a fungal population is then a result of combination between the fungicide risk, the pathogen risk and the usage risk. For example, the QoI (strobilurin-based) fungicides are single site fungicides subject to single-change resistance within the target gene and hence are at high risk for resistance that may appear abruptly. Multi-site fungicides interfere with several metabolic processes of the fungus and hence several mutations affecting many sites in the fungus would be needed for resistance to develop, which is often deleterious for the fungus survival. Consequently, the risk of resistance to these fungicides is low. Typically, these fungicides are protectant and inhibit spore germination. Fungicides used to manage apple scab in Canada are described in Table 2. 


\begin{tabular}{|c|c|c|c|c|}
\hline $\begin{array}{l}\text { FRAC } \\
\text { CODE }\end{array}$ & $\begin{array}{c}\begin{array}{c}\text { Mode of } \\
\text { action }\end{array} \\
\end{array}$ & $\begin{array}{c}\text { Group } \\
\text { name }\end{array}$ & $\begin{array}{l}\text { Chemical } \\
\text { group }\end{array}$ & $\begin{array}{c}\text { Active } \\
\text { ingredient }\end{array}$ \\
\hline 3 & $\begin{array}{l}\text { C14- demethylase in } \\
\text { sterol biosynthesis } \\
\text { (erg11/cyp51) }\end{array}$ & $\begin{array}{l}\text { DMI-fungicides } \\
\text { (DeMethylation } \\
\text { inhibitors) }\end{array}$ & triazoles & flusilazole \\
\hline 3 & $\begin{array}{l}\text { C14- demethylase in } \\
\text { sterol biosynthesis } \\
\text { (erg11/cyp51) }\end{array}$ & $\begin{array}{l}\text { DMI-fungicides } \\
\text { (DeMethylation } \\
\text { Inhibitors) }\end{array}$ & triazoles & myclobutanil \\
\hline 9 & $\begin{array}{c}\text { methionine } \\
\text { biosynthesis } \\
\text { (proposed) (cgs gene) }\end{array}$ & $\begin{array}{c}\text { AP - fungicides } \\
\text { (Anilino- Pyrimidines) }\end{array}$ & $\begin{array}{c}\text { anilino- } \\
\text { pyrimidines }\end{array}$ & cyprodinil \\
\hline 9 & $\begin{array}{c}\text { methionine } \\
\text { biosynthesis } \\
\text { (proposed) (cgs gene) }\end{array}$ & $\begin{array}{c}\text { AP - fungicides } \\
\text { (Anilino- Pyrimidines) }\end{array}$ & $\begin{array}{c}\text { anilino- } \\
\text { pyrimidines }\end{array}$ & pyrimethanil \\
\hline 11 & $\begin{array}{c}\text { complex III: } \\
\text { cytochrome bc1 } \\
\text { (ubiquinol oxidase) } \\
\text { at Qo site (cyt b gene) }\end{array}$ & $\begin{array}{l}\text { QoI-fungicides } \\
\text { (Quinone outside } \\
\text { Inhibitors) }\end{array}$ & $\begin{array}{l}\text { oximino } \\
\text { acetates }\end{array}$ & $\begin{array}{l}\text { kresoxim- } \\
\text { methyl }\end{array}$ \\
\hline 11 & $\begin{array}{c}\text { complex III: } \\
\text { cytochrome bc1 } \\
\text { (ubiquinol oxidase) } \\
\text { at Qo site (cyt b gene) }\end{array}$ & $\begin{array}{l}\text { QoI-fungicides } \\
\text { (Quinone outside } \\
\text { Inhibitors) }\end{array}$ & $\begin{array}{l}\text { oximino } \\
\text { acetates }\end{array}$ & trifloxystrobin \\
\hline $7+11$ & $\begin{array}{c}\text { complex II: } \\
\text { succinate- } \\
\text { dehydrogenase + } \\
\text { complex III: } \\
\text { cytochrome bc1 } \\
\text { (ubiquinol oxidase) } \\
\text { at Qo site (cyt b gene) }\end{array}$ & $\begin{array}{l}\text { SDHI (Succinate } \\
\text { dehydrogenase } \\
\text { inhibitors) + QoI- } \\
\text { fungicides (Quinone } \\
\text { outside Inhibitors) }\end{array}$ & $\begin{array}{c}\text { pyridine- } \\
\text { carboxamides } \\
+ \text { methoxy- } \\
\text { acrylates }\end{array}$ & $\begin{array}{l}\text { boscalid }+ \\
\text { pyraclostrobi } \\
n\end{array}$ \\
\hline $29+M$ & $\begin{array}{c}\text { uncouplers of } \\
\text { oxidative } \\
\text { phosphorylation }+ \\
\text { multi-site contact } \\
\text { activity }\end{array}$ & -- & $\begin{array}{l}\text { dinitrophenyl } \\
\text { crotonates }\end{array}$ & $\begin{array}{l}\text { dinocap + } \\
\text { mancozeb }\end{array}$ \\
\hline M & $\begin{array}{l}\text { multi-site contact } \\
\text { activity }\end{array}$ & Phthalimides & phthalimides & captane \\
\hline U12 & $\begin{array}{l}\text { unknown mode of } \\
\text { action }\end{array}$ & Guanidines & guanidines & dodine \\
\hline M & $\begin{array}{l}\text { multi-site contact } \\
\text { activity }\end{array}$ & $\begin{array}{c}\text { dithiocarbamates and } \\
\text { relatives }\end{array}$ & $\begin{array}{c}\text { dithio- } \\
\text { carbamates }\end{array}$ & mancozeb \\
\hline M & $\begin{array}{l}\text { multi-site contact } \\
\text { activity }\end{array}$ & $\begin{array}{c}\text { dithiocarbamates and } \\
\text { relatives }\end{array}$ & $\begin{array}{c}\text { dithio- } \\
\text { carbamates }\end{array}$ & metiram \\
\hline
\end{tabular}

Table 2. Description of the fungicides registered in Canada for management of apple scab (Venturia inaequalis). 
Disease Decision Support Systems:

Their Impact on Disease Management and Durability of Fungicide Effectiveness

\begin{tabular}{|c|c|c|c|c|c|c|c|}
\hline \multirow{2}{*}{$\begin{array}{c}\begin{array}{c}\text { Active } \\
\text { ingredient }\end{array} \\
\text { fFlusilazole }\end{array}$} & \multirow{2}{*}{$\begin{array}{c}\begin{array}{c}\% \text { active } \\
\text { ingredient }\end{array} \\
20\end{array}$} & \multicolumn{2}{|c|}{$\begin{array}{l}\text { Recommended } \\
\text { dose range } \\
\text { LOW to HIGH } \\
\text { (kg or L/ha) }\end{array}$} & \multirow{2}{*}{$\begin{array}{c}\text { EIQ } \\
45.94 \\
\end{array}$} & \multicolumn{2}{|c|}{$\begin{array}{l}\text { FIELD EIQ } \\
\text { range LOW to } \\
\text { HIGH }\end{array}$} & \multirow{2}{*}{$\begin{array}{c}\begin{array}{c}\text { Resistance } \\
\text { risk }\end{array} \\
\text { medium }\end{array}$} \\
\hline & & 0.10 & 0.20 & & 0.92 & 1.84 & \\
\hline myclobutanil & 40 & 0.34 & 0.34 & 24.01 & 3.27 & 3.27 & medium \\
\hline cyprodinil & 75 & 0.37 & 0.37 & 26.77 & 7.43 & 7.43 & medium \\
\hline pyrimethanil & 40 & 0.75 & 1.00 & 12.67 & 3.80 & 5.07 & medium \\
\hline $\begin{array}{c}\text { kresoxim- } \\
\text { methyl }\end{array}$ & 50 & 0.18 & 0.36 & 15.07 & 1.36 & 2.71 & high \\
\hline trifloxystrobin & 50 & 0.14 & 0.18 & 29.78 & 2.08 & 2.61 & high \\
\hline $\begin{array}{c}\text { boscalid + } \\
\text { pyraclostrobin }\end{array}$ & $\begin{array}{c}25.2 \% \\
\text { boscalid }+ \\
12.8 \% \\
\text { pyraclostrobin }\end{array}$ & 1.00 & 1.20 & $\begin{array}{c}26.44 \\
+ \\
27.01\end{array}$ & 10.12 & 12.14 & $\underset{\text { high }}{\text { medium }}+$ \\
\hline $\begin{array}{l}\text { dinocap + } \\
\text { mancozeb }\end{array}$ & $\begin{array}{c}4.7 \% \text { dinocap } \\
+72 \% \\
\text { mancozeb }\end{array}$ & 6.75 & 6.75 & 46.51 & 244.25 & 244.25 & $\begin{array}{c}\text { low / } \\
\text { unknown } \\
\text { - low }\end{array}$ \\
\hline captane & 50 & 3.00 & 6.00 & 15.77 & 23.66 & 47.31 & low \\
\hline dodine & 65 & 1.08 & 3.25 & 23.45 & 16.46 & 49.54 & $\begin{array}{l}\text { Low to } \\
\text { medium } \\
\text { risk. }\end{array}$ \\
\hline mancozeb & 75 & 5.00 & 6.00 & 25.72 & 96.45 & 115.74 & low \\
\hline metiram & 80 & 4.50 & 6.00 & 40.61 & 146.20 & 194.93 & low \\
\hline
\end{tabular}

Table 3. Risk of resistance development and environmental impact of the fungicides registered in Canada for management of apple scab ( $V$. inaequalis).

Environmental Impact Quotient (EIQ): The Environmental Impact Quotient (EIQ) has been used to classify toxicological data available on some common pesticides into a practical form for application usage by taking in consideration most of the environmental concern in agriculture. As stated by Kovach et al. (1992), each pesticide has an EIQ reflecting its impact on consumers, farm workers and a combination of different living organisms in the ecosystem. From this EIQ value, a field use rating can be calculated using a simple formula: Field EIQ $=$ EIQ * \% active ingredient * rate of application.

\subsection{Resistance management strategies}

Despite the availability of a large variety of fungicides, for most of them, there is a conflict between environment safety profile and risk for resistance (Table 3). Most of the fungicides at moderate to high risk for resistance including DMIs and QoIs have a good human and environment safety profile. On the contrary, multi-site fungicides which are at low risk for resistance generally have a bad environment safety profile (Table 3) (Schneider and Dickert, 1994). To maintain the efficacy of fungicides, it is important to implement fungicide resistance program, ideally before resistance becomes a problem. In practice, most growers do not know the level of fungicide resistance present in the pathogen's population. In 
absence of knowledge on the level of resistance and of tools to accurately predict how fast resistance will develop, it is advisable to follow some anti-resistance measures such as use at-of risk fungicides only when needed ideally only at key times in the season, when disease pressure is low use fungicide at low risk for resistance. If at-risk fungicides must be used, they should be mixed with a fungicide at low risk, used only a few times per season and used in rotation with fungicide with a different mode of action. For the most part, evaluations of the effectiveness of these strategies have not been assessed scientifically. The merits of tank-mixing compared to alternating sprays have been debated. Some theorize that tank-mixing reduces selection pressure only when the partner fungicide is highly effective and good coverage is achieved. Alternating fungicides is thought to act by reducing the time of exposure. In practice, examples can be cited for the effectiveness of both approaches. Nevertheless, both practices are more effective when cultural practices are implemented to reduce disease pressure. To prolong the effectiveness of fungicides and usefulness to growers, implementation of resistance management strategies is crucial. However, monitoring resistance levels in pathogen populations is essential for assessing risk and evaluating the effectiveness of disease and anti-resistance management practices.

\subsection{Monitoring fungicide resistance}

Regardless of the method used, monitoring the sensitivity of fungicide resistance of fungal population is time consuming and costly. Methods for monitoring resistance are described in detail in FRAC monograph No 3. (Russel, 2004). In brief, these methods could be broadly grouped in biological and molecular methods. Biological methods are based on the detection of the baseline sensitivity difference of a sample from the wild type population (not exposed to the fungicide). These tests can be performed either on solid agar in Petri dishes with visual rating (germination, germ tube elongation and mycelia growth) or in liquid medium using a spectrophotometer or biomass weight (rating of mycelial growth

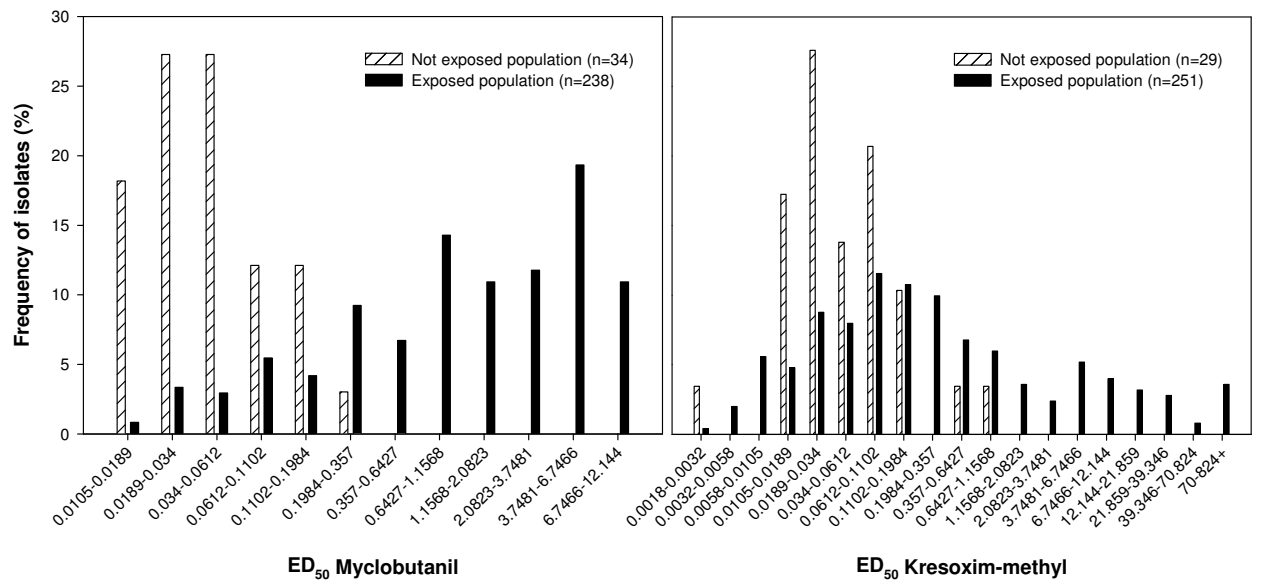

Fig. 7. Frequency distributions of $\mathrm{ED}_{50}$ values for myclobutanil and kresoxim-methyl of $V$. inaequalis in 2003 from orchards located in eastern Canada. ED 50 values (in $\mu \mathrm{g} / \mathrm{ml}$ ) are based on mycelial radial growth on PDA amended with different doses of the fungicides (from Jobin and Carisse, 2007). 
only). This method was widely used to study the status of resistance in $V$. inaequalis populations from various apple production areas (Carisse and Jobin, 2010; Carisse and Pelletier, 1994; Jobin and Carisse, 2007) (Fig. 7).

Molecular methods are based on the detection and/or quantification of the mutations in the fungal genes that confer the resistance to the fungicide. Depending on the type of resistance, single mutation, single nucleotide polymorphism (SNP), or more than one SNPs are involved. Even when only one mutation is detected in most of the resistant isolates, it may be not reliable to monitor resistance based on this single mutation without considering that some resistant isolates might have other mutations and that the proportion of these may increases as the population is exposed to the fungicide. Nevertheless, molecular methods have helped understand the mechanisms of fungicide resistance and develop fast method for detection or quantification of resistant pathogen genotypes. For $V$. inaequalis, molecular methods were developed only for resistances whose mechanism was fully identified, i.e. resistance to anti-microtubules in benzimidazoles (carbendazim, thiophanate-methyl) and inhibitors of mitochondrial complex III (strobilurins) (Table 4). Resistance to multisite inhibitors, DMIs, anilinopyrimidines and SDHIs are still monitored with biological tests. For benzimidazoles and QoIs, resistance was found to be determined by single mutation within the target genes ( $\beta$-tubulin and cytochrome b, respectively) (Quello et al, 2010; Fontaine et al, 2008). These mutations were detected after partial PCR amplification of these genes and digestion of the PCR product by a restriction enzyme that recognizes the restriction site generated (or lost) by the mutation determining resistance (PCR-RFLP or CAPS test). Digestion patterns are scored on an electrophoresis gel and are a direct indicator of the presence of the mutation. This test was developed for mono-lesion isolates, in the case of benzimidazoles and for bulk population of spores in the case of QoIs. Moreover, an allelespecific PCR test (AS-PCR) was also developed to detect the G143A change within the cytochrome $\mathrm{b}$ of $V$. inaequalis (Fontaine et al, 2008). Roughly, PCR was achieved using primers differing by their $3^{\prime}$ nucleotides, enabling to detect specifically either the susceptible or the resistant allele of the sample. This method was particularly adapted for bulk population samples because of its higher specificity. At last, when molecular and phenotypic data are not coherent, sequencing or pyrosequencing are largely used by researchers to characterize novel mutations within the target gene or to refute the hypothesis of target alteration as a possible resistance mechanism.

\section{A DDSS that integrates the three components of the apple scab pathosystem: Pathogen-host-environment}

The structure of DDSS for apple scab management varies from one simple model such as the Mills rules for infections, coupled with simple models such as ascospore maturity models up to more complex simulation models (Rossi et al., 2007). The simple rule-based DDSS may not be sufficient to make proper estimation of risk, while the complexity of some simulation models refrain growers from using them. In addition, the decision as to whether to spray also depends on considerations not related to the pathogen development among which the time elapsed since the last spray, amount of weathering of last fungicide spray, time to the next forecasted infection period, opportunity to apply the fungicide and amount of new foliage not protected by the last fungicide spray. They are only few DDSS that consider leaf growth as a risk factor even though, from a yield loss perspective, it is probably one of the most important factors. Considering that the main goal of most scab management program is to 


\begin{tabular}{|c|c|c|}
\hline Resistance mechanism & Resistance detection method & Reference \\
\hline $\begin{array}{l}\text { Benzimidazoles: } \\
\text { Target alteration: } \\
3 \text { altered codons and } 4 \\
\text { resistant alleles in the } \beta \text { - } \\
\text { tubulin gene }\end{array}$ & $\begin{array}{l}\text { In-vitro (single-spore isolates; } \\
\text { mycelial growth) } \\
\text { PCR-RFLP (single spore- } \\
\text { isolates) }\end{array}$ & Quello et al, 2010 \\
\hline $\begin{array}{l}\text { Anilinopyrimidines: } \\
\text { Unknown }\end{array}$ & $\begin{array}{l}\text { In-planta (bulk spores } \\
\text { populations; apple seedlings) }\end{array}$ & $\begin{array}{l}\text { FRAC } \\
\text { http:/ / www.frac.info }\end{array}$ \\
\hline $\begin{array}{l}\text { DMIs: } \\
\text { Unknown } \\
\text { Possibly target alteration }\end{array}$ & $\begin{array}{l}\text { In-vitro (mono-lesion spore } \\
\text { suspension; germination and } \\
\text { germ-tube elongation) } \\
\text { In-planta (bulk spores } \\
\text { populations; apple seedlings) }\end{array}$ & $\begin{array}{l}\text { Gao et al, } 2009 \\
\text { Jobin and Carisse, } \\
2007 \\
\text { FRAC } \\
\text { http:/ / www.frac.info }\end{array}$ \\
\hline $\begin{array}{l}\text { QoIs: } \\
\text { Target alteration: } \\
\text { G143A change in the } \\
\text { cytochrome b change } \\
\text { Unknown resistance } \\
\text { mechanism (detoxification or } \\
\text { activation of the alternative } \\
\text { oxidase?) }\end{array}$ & $\begin{array}{l}\text { In-vitro (bulk spores } \\
\text { populations; germination, } \\
\text { germ-tube elongation and } \\
\text { mycelium growth) } \\
\text { AS- PCR (bulk spore } \\
\text { population) } \\
\text { CAPS (bulk spore population) }\end{array}$ & $\begin{array}{l}\text { FRAC } \\
\text { http:/ / www.frac.info } \\
\text { Steinfeld et al, } 2001 \\
\text { Jobin and Carisse, } \\
2007 \\
\text { Fontaine et al, } 2008\end{array}$ \\
\hline
\end{tabular}

Table 4. Summary of the methods used to monitor resistance in Venturia inaequalis for different class of fungicides.

control foliar scab during the primary infection period in order to avoid secondary epidemic build up during the summer months, knowing how many leaves are protected is crucial.

Concept. The critical time for spraying fungicide against apple scab is during the peak of ascospore release and the period of rapid leaf emergence (Fig. 8). Currently, most apple scab management programs are "pathogen oriented" in other words based on the estimated amount of mature ascospores of $V$. inaequalis and on the predicted severity of ascospore infection (MacHardy 1996). However, another strategy more "host oriented" is to prevent ascospore infections by protecting new leaves (susceptible to $V$. inaequalis) with appropriate fungicides. Hence, we developed a new DDSS for assessing the day-to-day variation in risk of primary infection and weekly risk for secondary infections by $V$. inaequalis. The system comprises three components to time fungicide sprays against primary infections and one component to time fungicide sprays against secondary infections. The need for fungicide sprays are determined based on risk of primary infections estimated from 1) the number of unprotected leaves (new leaves since the last spray), 2) the availability of ascospores calculated from degree-day accumulation, expressed as low, or high availability of ascospores, and 3) infection risk based on Mills table, expressed as no, low, moderate and 
high risk. The need for fungicide sprays during the summer is based on monitoring leaf scab incidence and using a threshold of 0.5 or $1.0 \%$ leaf scabbed (Carisse et al., 2009). Assessment of disease risk occurs daily, although hourly weather data are required to calculate degreedays and identify the beginning of rainfall event, duration of surface wetness and temperature.

Component 1. Estimation of daily leaf emergence. Because temperature has been reported to be the main factor affecting early season leaf emergence, cumulative degree-days were used as a predictor of leaf emergence (Carisse et al., 2008). Emergence of cluster and terminal apple leaves was monitored over several years for different rootstocks, cultivars and sites. The pattern of both cluster and terminal leaf emergence was not affected by rootstocks or cultivars, although variations were observed among years and sites. These patterns of leaf emergence on cluster and terminal shoots as a function of cumulative degree-days (Tbase $5^{\circ} \mathrm{C}$ ) were described by the Richards and the Weibull models, respectively, (Carisse et al., 2008). In Eastern Canada, the first cluster leaves emerged from the end of April to early May, and then the number of leaves per cluster shoot increased rapidly to reach a plateau of about eight leaves per shoot in mid-May (Fig. 8). The pattern of leaf emergence is different for the terminal leaves. In Eastern Canada, the first leaves emerged during the first week of May and emergence of subsequent leaves was gradual and at a lower rate than for the cluster leaves until the end of June, which corresponded more or less to the end of the primary scab infection period (Fig. 8).

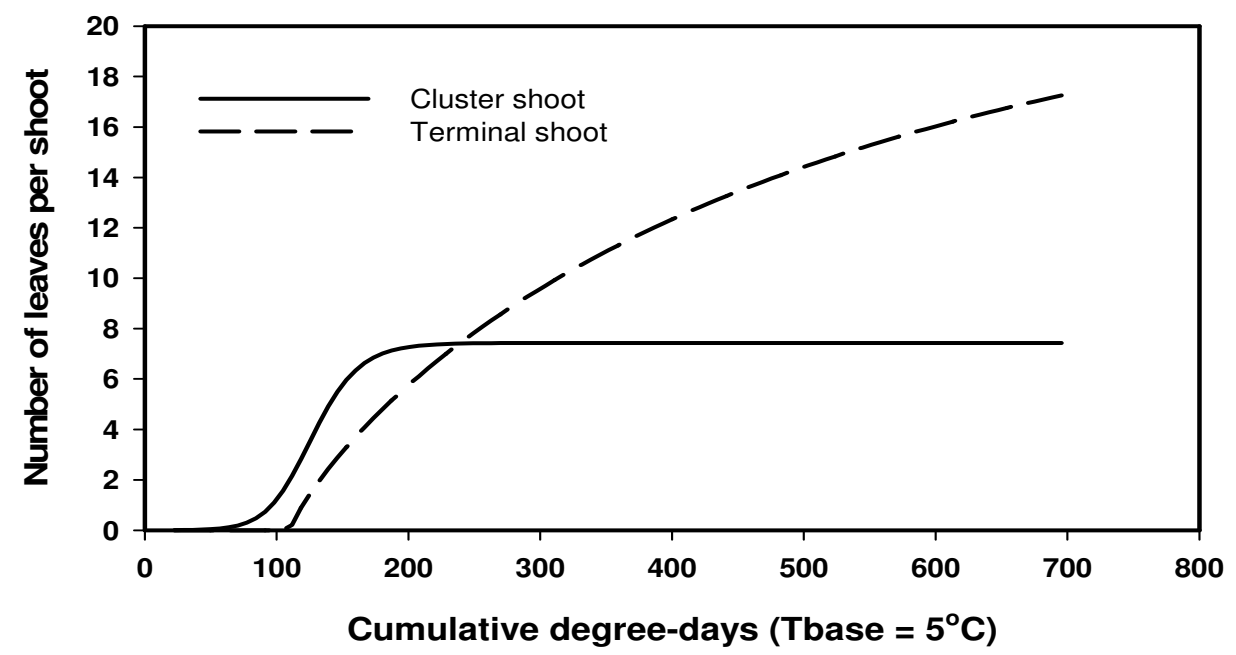

Fig. 8. Temporal progress of the number of leaves per cluster or terminal apple tree shoot as a function of accumulation of degree days $\left(\right.$ Tbase $\left.=5^{\circ} \mathrm{C}\right)$ since April $1^{\text {st }}$.

Component 2. Estimation of ascospore availability. The DDSS assume that there will always be mature ascospores at bud break and that the amount of primary inoculum (ascospores) in the overwintering leaves is low (well managed orchard with less than 5\% leaf scab at harvest the previous fall) or high (poor control during the previous season and $>5 \%$ leaf scab at harvest the previous fall). The rate at which ascospores mature in the overwintering leaves on the orchard floor is determined mainly by temperature (Gadoury 
and MacHardy, 1982). In our DDSS, the biofix to begin accumulating DD is April $1^{\text {st }}$ and the base temperature is $5 \circ \mathrm{C}$. Regardless of the potential ascospore dose (PAD), ascospore maturation occurs in three phases. In the first stage, ascospores mature slowly because temperature is usually cooler, then maturation accelerates with increasing temperatures. Finally, the last ascospores mature until exhaustion of the stock in pseudothecia. In practice, there is so much variation in the proportion of mature ascospores between leaves and among cultivars (Fig.5.) (Carisse et al., 2006) that degree days were used to determine the period of availability of ascospores from about 50 to 350 CDD. At 350 the DDSS assume that over $95 \%$ the ascospore supply is depleted if sufficient rain events have occurred). This marks the end of primary infection season. When the CDD is between 50 and 100 or $>300$ the availability of ascospore was considered as low, while when the CDD are between 100 and 300 the availability was considered as high. Ascospore release is strongly light dependent (Brooke, 1969); hence the DDSS assume that only a small portion of available ascospores is released at night. Ascospores are not released to any significant extent during night hours in low inoculum orchards (MacHardy, 1998). In high inoculum orchards, although the percentage of ascospore released is small, the total number of ascospores released may cause significant primary infections. Hence in the DDSS ascospore release is triggered by a rain that begins during the day or at any time of the day in low and high primary inoculum orchards, respectively.

Component 3. Estimation of primary infection risk. Conditions suitable for the infection of leaf and fruit tissues by ascospores are identified using the surface wetness duration and temperature criteria of Mills \& Laplante (1954), with the modification of MacHardy \& Gadoury (1989). The algorithm outputs a continuous variable based on four wetness-based risk categories: nil, light, moderate and severe (Fig. 6). Since ascospore ejections during the night are low, it is possible to exclude nocturnal hours of leaf wetness (except in the case of a massive ejection period in a high inoculum orchard). When two wet events (rain) are interrupted by a non-wet period with high relative humidity $(<85 \%)$ calculation is done on the entire period. On the other hand, if the interruption is dry ( $\mathrm{HR}<85 \%$ and $<24$ hours), the two wet events are added without consideration for the dry period (Becker et al.,1994).

Component 4. Determining the need for fungicide sprays against secondary scab. Summer scab is managed based on a foliar scab action threshold of 0.005 scabbed leaves per shoot $(0.5 \%)$ and classification of leaf scab incidence as above or below the threshold using the SSCP developed by Carisse et al. (2009). The first orchard classification is conducted in mid-June and the orchard is classified as above or below the action threshold of $0.5 \%$ foliar scab or as in the "no decision" zone. The following criteria is used to time fungicide sprays: 1) if the orchard is classified as above the action threshold, a 7 to 14-day summer spray program is initiated and continued until harvest unless a prolonged dry period is forecasted, in which case the orchard is reassessed. Unless that reassessment classified the orchard as below the threshold, the summer spray program is maintained. 2) if the orchard is classified as below the action threshold, fungicide spray applications are postponed until the threshold is reached. If the action threshold of $0.5 \%$ foliar scab is not reached by midAugust, a less conservative threshold of $1.0 \%$ foliar scab could be used from then until harvest. 3) If the orchard is classified as in the "no decision" zone, sampling is repeated 7 to 14 days later depending on the frequency of rainy days. With the SSCP, a minimum of 50 and a maximum of 240 shoots per orchard section are sampled, and care must be taken to select shoots that were representative of the trees (i.e. shoots at the top, bottom, edges, and center of the canopy). 

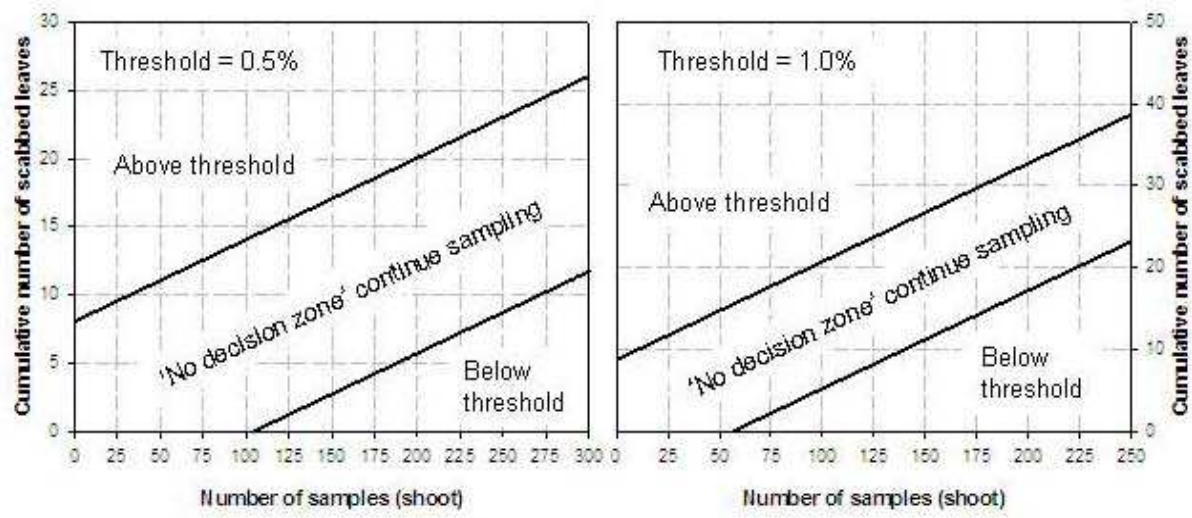

Fig. 9. Sequential sampling for classification plans for classifying scab incidence in apple orchards as above or below action thresholds of 0.005 (A) and 0.01 (B) scabbed leaves per shoot (from Carisse et al., 2009).

Orchard testing of the DDSS. The DDSS was tested in 2008, 2009, and 2010 at the Agriculture and Agri-Food Canada Experimental Farm, in Frelighsburg, Quebec, Canada. The DDSS was tested in a 0.72 ha orchard implemented in 2002 with a tree density of 1470 tree per ha and composed of six apple cultivars with various level of susceptibility to $V$. inaequalis (Dewdney et al. 2003): Spartan, Cortland, McIntosh, Paulared, Empire and Gingergold, grafted on M9, B9, M9, M9, EM26, B9 rootstocks, respectively. An additional block planted with the cultivar McIntosh grafted on M9 was used as a control and sprayed according to the standard practices. The DDSS was used to identifying the key time for fungicide applications based on the number of leaves unprotected (new leaves since the last spray) with an action threshold of 0.5 new leaves. The choice of fungicide was done according to the anti-resistance management approach describe previously. Briefly, at-risk fungicides were used only during period of high risk for disease development, each at-risk fungicide was not used more than twice per season and when possible tank-mixed with fungicide at low risk for resistance. Fungicides at high risk for the environment were used to control secondary infections only when the disease was above the action threshold. A few days before harvest, leaf scab incidence was estimated from a sample of 100 shoots randomly selected within each orchard section, and fruit scab incidence was estimated from 25 fruits on 10 trees selected at random within each section. The number of fungicide sprays and the seasonal environmental impact quotient (EIQ) was calculated for each cultivar (Kovach et al., 1992).

Over the three seasons of the trial, the incidence of scab and the weather conditions varied considerably. In 2008 and 2009, the weather conditions during the spring were highly favorable for apple scab development, while in 2010 rains events were sporadic. Nevertheless, for the three years, it was possible to maintain the disease under the economic threshold of $1 \%$ fruit scab at harvest. However, in 2009 leaf scab at harvest on the highly susceptible cultivar was above the threshold of 5\% leaf scab, hence in 2010 it was treated as high inoculum orchards (MacHardy, 1998). Despite the high level of leaf scab in 2009, the incidence of leaf scab in 2010 was low, showing the importance of spring conditions in determining the severity of epidemics. The difference in weather conditions during both the 
primary and secondary scab seasons demonstrated the value of using DDSS to assist in fungicide spray decisions. In 2008 and 2009, the DDSS enable better timing of fungicide sprays compared to the standard spray program resulting in better scab control with fewer sprays (Fig. 10). In 2010, a season with scab risk much lower, the DDSS resulted in large reduction in amount of fungicides used (Fig. 10). The DDSS provided information valuable in timing fungicide sprays. Overall, the DDSS enable a better scab control with minimum usage of at risk fungicides and much lower environmental impact of the spray program (Fig. 10) (Table 5).
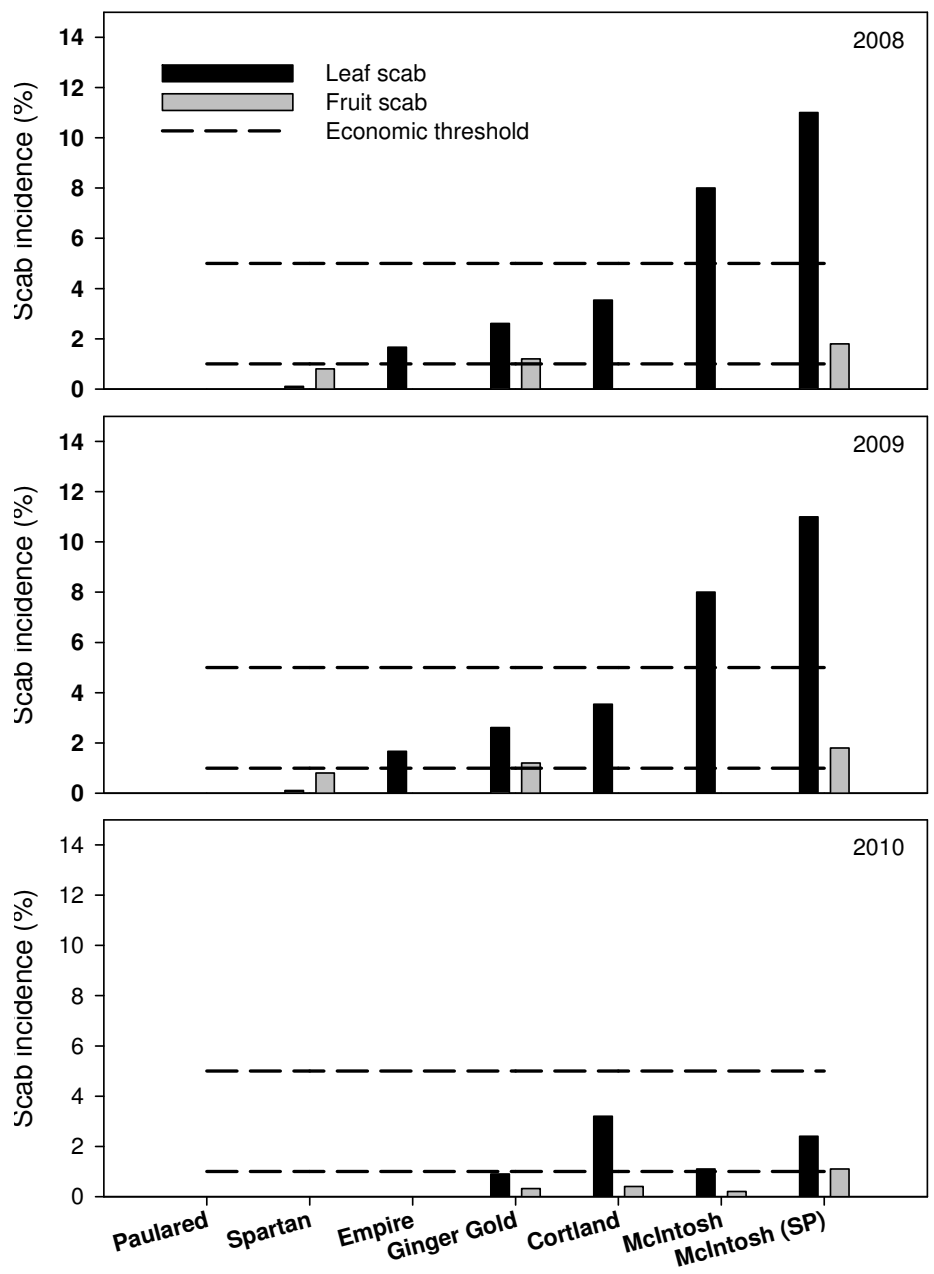

Apple cultivars

Fig. 10. Leaf and fruit apple scab incidence at harvest on cultivars with different susceptibility from orchards managed using the DDSS and compared to a standard fungicide spray program (McIntrosh-SP). 


\begin{tabular}{|c|c|c|c|}
\hline Cultivar & $\begin{array}{c}\text { Number of } \\
\text { at risk fungicides }\end{array}$ & $\begin{array}{c}\text { Total number of } \\
\text { applications }\end{array}$ & EIQ \\
\hline Paulared & 1.67 & 6.33 & 448.00 \\
\hline Spartan & 2.67 & 9.33 & 657.42 \\
\hline Empire & 2.67 & 10.33 & 746.05 \\
\hline Ginger Gold & 3.00 & 11.00 & 746.05 \\
\hline Cortland & 3.00 & 12.00 & 939.08 \\
\hline McIntosh & 3.00 & 12.67 & 1019.83 \\
\hline McIntosh (SP) & 4.67 & 15.67 & 1230.32 \\
\hline
\end{tabular}

Table 5. Fungicide use pattern for apple cultivars with different level susceptibility to $V$. inaequalis managed using the DDSS and for the cultivar McIntosh managed using a standard spray program.

\section{Conclusion}

In this review we demonstrated the complexity of disease management decision making and the usefulness of DDSS in identifying the key time for applying fungicides. Much more information will be needed to demonstrate the long term effects of optimal use of fungicide on the development of resistance and hence on the durability of the fungicide effectiveness. Most of the DDSS available for management of apple scab are entirely weather-based. With our DDSS, growers are required to inspect their orchard for the presence of leaf and fruit scab. This may be regarded as time consuming but determining if the disease is above or below an action threshold is the foundation of integrated disease management. If we consider the long term value of optimal fungicide usage, it is certainly worth doing it. Ideally, fungicide resistance should also be monitored routinely. Once rapid and inexpensive methods become available, it will be possible to detect shift in $V$. inaequalis population and to adjust the fungicide use pattern accordingly.

\section{References}

Aylor, D.E. (1998). The aerobiology of apple scab. Plant Disease, Vol. 82, No. 8, (August 1998) pp. 838-849, ISSN 0191-2917

Becker C.M., Burr T.J. \& Smith C.A. (1992). Overwintering of conidia of Venturia inaequalis in apple buds in New York orchards. Plant Disease, Vol. 76, No. 2, (Feb 1992) pp. 121126, ISSN 0191-2917

Becker C.M., \& Burr T.J. (1994). Discontinuous wetting and survival of conidia of Venturia inaequalis on apple leaves. Phytopathology, Vol. 84, No. 4, (April 1994) pp. 372-78, ISSN 0031-949X

Brook, P.J. (1969). Effects of light, temperature, and moisture on release of ascospores by Venturia inaequalis (Cke.) Wint. New Zealand Journal of Agricultural Research, Vol. 12, No. 1, (1969) pp. 214-227, ISSN0028-8233

Carisse, O., \& Jobin, T. (2010). Resistance to dodine in populations of Venturia inaequalis in Quebec, Canada. Online. Plant Health Progress, doi:10.1094/PHP-2010-0614-01-RS.

Carisse, O., \& Pelletier, J.R. (1994). Sensitivity distribution of Venturia inaequalis to fenarimol in Quebec apple orchards. Phytoprotection, Vol. 75, No. 1, (1994) pp. 35-43, ISSN0031-9511 
Carisse, O., Rolland, D., Talbot, B. \& Savary, S. (2006). Heterogeneity of the aerial concentration and deposition of ascospores of Venturia inaequalis within a tree canopy during the rain. European Journal of Plant Pathology, Vol. 117, No. 1, (January 2007) pp. 13-24, ISSN0929-1873

Carisse, O., Jobin, T. \& Bourgeois, G. (2008). Predicting apple leaf emergence from degreeday accumulation during the primary scab period. Canadian Journal of Plant Science, Vol. 88, No. 1, (January 2008) pp. 229-238, ISSN 0008-4220

Carisse, O., Meloche, C., Boivin, G., \& Jobin, T. (2009). Action thresholds for summer fungicide sprays and sequential classification of apple scab incidence. Plant Disease, Vol. 93, No. 5, (May 2009) pp. 490-498, ISSN 0191-2917

Charest, J., Dewdney, M., Paulitz, T.C., Philion, V., \& Carisse, O. (2002). Spatial distribution of Venturia inaequalis airborne ascospores in orchards. Phytopathology, Vol. 92, No. 7, (July 2002) pp. 769-779, ISSN 0031-949X

Dewdney, M, Charest, J., Paulitz, T. \& Carisse. O. (2003). Multivariate analysis of apple cultivar susceptibility to Venturia inaequalis under greenhouse conditions. Canadian Journal of Plant Pathology, Vol. 25, No. 4, (December 2003) pp. 387-400, ISSN 0706-0661

Fontaine, S., Remuson, F., Fraissinet-Tachet, L., Micoud, A., Marmeisse, R. \& Melayahb, D. (2008). Monitoring of Venturia inaequalis harbouring the QoI resistance G143A mutation in French orchards as revealed by PCR assays. Pest Management Science, Vol. 65, No. 1, (January 2009) pp. 74-81, ISSN 1526-498X

Gadoury, D.M., \& MacHardy, W.E. (1982). A model to estimate the maturity of ascospores of Venturia inaequalis. Phytopathology, Vol. 72, No. 7, (July 1982) pp. 901-904, ISSN0031-949X

Gadoury, D.M., \& MacHardy W.E. (1986). Forecasting ascospore dose of Venturia inaequalis in commercial apple orchards. Phytopathology, Vol. 76, No. 1, (January 1986) pp. 112-118, ISSN 0031-949X

Gao, L., Berrie, A., Yang, J., \& Xu, X. (2009). Within- and between-orchard variability in the sensitivity of Venturia inaequalis to myclobutanil, a DMI fungicide, in the UK. Pest Management Science, Vol. 65, No. 11, (November 2009) pp. 1241-1249, ISSN 1526498X

Hartman, J.R., Parisi, L., \& Bautrais, P. (1999). Effect of leaf wetness duration, temperature, and conidial inoculum dose on apple scab infections. Plant Disease, Vol. 83, No. 6, (June 1999) pp. 531-534, ISSN 0191-2917

Holb, I.J., Heijne, B., \& Jeger, M.J. (2003). Summer epidemics of apple scab: The relationship between measurements and their implications for the development of predictive models and threshold levels under different disease control regimes. Journal of Phytopathology, Vol. 151, No. 6, (June 2003) pp. 335-343, ISSN 0931-1785

Holb, I.J., Heijne, B., Withagen, J.C.M., Gall, J.M., \& Jeger, M.J. (2005). Analysis of summer epidemic progress of apple scab at different apple production systems in the Netherlands and Hungary. Phytopathology, Vol. 95, No. 9, (September 2005) pp.1001-1020, ISSN 0031-949X

James, J.R., \& Sutton, T.B. (1982). A model for predicting ascospore maturation of Venturia inaequalis. Phytopathology, Vol. 72, No. 8, (August 1982) pp.1081-1085, ISSN 0031949X 
Jobin, T., \& Carisse, O. (2007). Incidence of myclobutanil- and kresoxim-methyl-insensitive isolates of Venturia inaequalis in Quebec orchards. Plant Disease, Vol. 91, No. 10, (October 2007) pp. 1351-1358, ISSN 0191-2917

Kovach, J., Petzoldt, C., Degni, J. \& Tette, J. (1992). A Method to Measure the Environmental Impact of Pesticides. New York's Food and Life Sciences Bulletin, No.139, (1992) pp. 139, ISSN0362-0069

MacHardy, W.E. (1996). Apple Scab: Biology, Epidemiology, and Management. American Phytopathological Society (APS Press), ISBN 0-89054-206-6, St. Paul, MN.

MacHardy, W.E. (1994). A "PAD" action threshold: The key to integrating practices for managing apple scab, In: Integrated Control of Pome Fruit Diseases. D.J. Butt, (Ed.) pp. 75-82, Norwegian journal of agricultural sciences. Supplement no. 17

MacHardy, W.E. (1998). Action thresholds for managing apple scab with fungicides and sanitation. Acta Horticulturae, Vol. 525, (March 2000) pp. 123-131, ISSN 0567-7572

MacHardy, W.E., \& Gadoury, D.M. (1989). A revision of Mills's criteria for predicting apple scab infection periods. Phytopathology, Vol. 79, No. 3, (March 1989) pp. 304-310, ISSN 0031-949X

MacHardy, W.E., Berkett, L.P., Neefus, C.D., Gotlieb, A.R., \& Sutton, D.K. (1999). An autumn foliar scab sequential sampling technique to predict the level of "scab-risk" next spring. Phytopathology, Vol. 89, (June 1999) S47, ISSN 0031-949X

Mills, W.D. (1944). Efficient use of sulfur dusts and sprays during rain to control apple scab. Cornell Extension Bulletin, No. 630, pp. 1-4.

Mills, W.D., \& Laplante, A.A. (1951). Diseases and insects in the orchard. Cornell Extension Bulletin, No. 711, 60 pages.

Proctor, J.T.A. (1982). Prediction of apple scab ascospore discharge using degree days. Horticultural Science, Vol. 17 pp. 496, ISSN 0862-867X

Quello, K.L., Chapman, K.S., \& Beckerman, J.L. (2010). In situ detection of benzimidazole resistance in field isolates of Venturia inaequalis in Indiana. Plant Disease, Vol. 94, No. 6, (June 2010) pp. 744-750, ISSN 0191-2917

Reardon, J.E., Berkett, L.P., Garcia, M.E., Gotlieb, A., Ashikaga T. \& Badger, G. (2005). Field evaluation of a new sequential sampling technique for determining apple scab “risk." Plant Disease, Vol. 89, No. 3, (March 2005) pp. 228-236, ISSN 0191-2917

Rossi, V., Ponti, I., Marinelli, M., Giosus, S., \& Bugiani, R. (2000). A new model estimating the seasonal pattern of air-borne ascospores on Venturia inaequalis (Cooke) Wint. in relation to weather conditions. Journal of plant pathology, Vol. 82, No. 2, (July 2000) pp. 111-118, ISSN 1125-4653

Rossi, V., Giosuè, S., \& Bugiani, R. (2007). A-scab (Apple-scab), a simulation model for estimating risk of Venturia inaequalis primary infections. Bulletin OEPP/EPPO Bulletin, Vol. 37, No. 2, (August 2007) pp. 300-308, ISSN 0250-8052

Russel, P.E. (2004). Sensitivity baselines in fungicide resistance research and management. FRAC Monograph, No. 3, Brussels.

Schneider, E.F., \& Dickert, K.J. (1994). Health costs and benefits of fungicides used in agriculture: a literature review. Journal of Agromedicine, Vol. 1, No. 1, (October 1994) pp. 19-37, ISSN: 1545-0813

Schwabe, W.F.S. (1980). Wetting and temperature requirements for apple leaf infection by Venturia inaequalis in South Africa. Phytophylactica, Vol. 12, No. 2, (1980) pp. 69-80. ISSN 0370-1263 
Schwabe, W.F.S., Jones, A.L. \& Jonker, J.P. (1984). Changes in the susceptibility of developing apple fruit to Venturia inaequalis. Phytopathology, Vol. 74, No. 1, (January 1894) pp. 118-121, ISSN 0031-949X

Schwabe W.F.S., Jones, A.L. \& van Blerk, E. (1989). Relation of degree-day accumulations to maturation of ascospores of Venturia inaequalis in South Africa. Phytophylactica, Vol. 21, No. 1, (1989) pp. 13-16, ISSN 0370-1263

Steinfeld, U., Sierotzki, H., Parisi, S., Poirey, S., and Gisi, U. (2001). Sensitivity of mitochondrial respiration to different inhibitors in Venturia inaequalis. Pest management science, Vol. 57, No. 9, (September 2001) pp. 787-896, ISSN 1526-498X

Stensvand, A., Gadoury, D.M., Amundsen, T., Semb, L., \& Seem, R.C. (1997). Ascospore release and infection of apple leaves by conidia and ascospores of Venturia inaequalis at low temperatures. Phytopathology, Vol. 87, No. 10, (October 1997) pp. 1046-1053, ISSN 0031-949X

Sys, S., \& Soenen, A. (1970). Investigations on the infection criteria of scab (Venturia inaequalis Cooke. Wint.) on apples with respect to the table of Mills and Laplante. Agricultura, Vol. 18, No. 3-4, (1970) pp. 3-8, ISSN 1581-5439

van der Scheer, H.A. Thesis. 1987. Supervised control of scab and powdery mildew on apple. Obstbau and Weinbau, Vol.24, pp. 249-251.

$\mathrm{Xu}, \mathrm{X} .$, \& Robinson, J. (2005). Modelling the effects of wetness duration and fruit maturity on infection of apple fruits of Cox's Orange Pippin and two clones of Gala by Venturia inaequalis. Plant Pathology, Vol. 54, No. 3, (June 2005) pp. 347-356, ISSN 1365-3059 


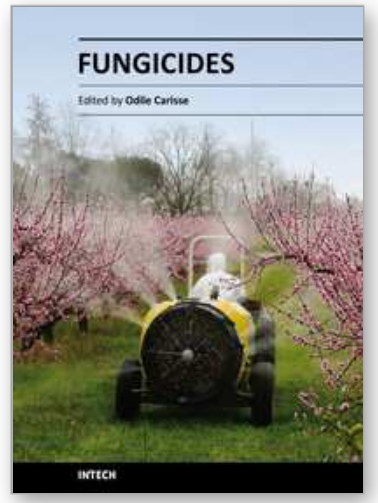

\author{
Fungicides \\ Edited by Odile Carisse
}

ISBN 978-953-307-266-1

Hard cover, 538 pages

Publisher InTech

Published online 14, December, 2010

Published in print edition December, 2010

Plant and plant products are affected by a large number of plant pathogens among which fungal pathogens. These diseases play a major role in the current deficit of food supply worldwide. Various control strategies were developed to reduce the negative effects of diseases on food, fiber, and forest crops products. For the past fifty years fungicides have played a major role in the increased productivity of several crops in most parts of the world. Although fungicide treatments are a key component of disease management, the emergence of resistance, their introduction into the environment and their toxic effect on human, animal, non-target microorganisms and beneficial organisms has become an important factor in limiting the durability of fungicide effectiveness and usefulness. This book contains 25 chapters on various aspects of fungicide science from efficacy to resistance, toxicology and development of new fungicides that provides a comprehensive and authoritative account for the role of fungicides in modern agriculture.

\title{
How to reference
}

In order to correctly reference this scholarly work, feel free to copy and paste the following:

Odile, Carisse, David-Mathieu, Tremblay, Tristan, Jobin, and Anne Sophie, Walker (2010). Disease Decision Support Systems: Their Impact on Disease Management and Durability of Fungicide Effectiveness, Fungicides, Odile Carisse (Ed.), ISBN: 978-953-307-266-1, InTech, Available from:

http://www.intechopen.com/books/fungicides/disease-decision-support-systems-their-impact-on-diseasemanagement-and-durability-of-fungicide-effe

\section{INTECH}

open science | open minds

\section{InTech Europe}

University Campus STeP Ri

Slavka Krautzeka 83/A

51000 Rijeka, Croatia

Phone: +385 (51) 770447

Fax: +385 (51) 686166

www.intechopen.com

\section{InTech China}

Unit 405, Office Block, Hotel Equatorial Shanghai

No.65, Yan An Road (West), Shanghai, 200040, China

中国上海市延安西路65号上海国际贵都大饭店办公楼 405 单元

Phone: +86-21-62489820

Fax: $+86-21-62489821$ 
(C) 2010 The Author(s). Licensee IntechOpen. This chapter is distributed under the terms of the Creative Commons Attribution-NonCommercialShareAlike-3.0 License, which permits use, distribution and reproduction for non-commercial purposes, provided the original is properly cited and derivative works building on this content are distributed under the same license. 